\title{
A small-volume multiplexed pumping system for automated, high-frequency water chemistry measurements in volume-limited applications
}

\author{
Bryan M. Maxwell ${ }^{1}$, François Birgand ${ }^{1}$, Brad Smith ${ }^{2}$, and Kyle Aveni-Deforge ${ }^{1}$ \\ ${ }^{1}$ Biological and Agricultural Engineering, North Carolina State University, 3110 Faucette Drive, Raleigh, 27695, USA \\ ${ }^{2}$ Sungate Design Group, 905 Jones Franklin Road, Raleigh, 27606, USA
}

Correspondence: Bryan M. Maxwell (bmmaxwel@ncsu.edu)

Received: 23 April 2018 - Discussion started: 31 May 2018

Revised: 26 September 2018 - Accepted: 9 October 2018 - Published: 30 October 2018

\begin{abstract}
An automated multiplexed pumping system (MPS) for high-frequency water chemistry measurements at multiple locations previously showed the ability to increase spatial and temporal data resolution and improve understanding of biogeochemical processes in aquatic environments and at the land-water interface. The design of the previous system precludes its use in volume-limited applications in which highly frequent measurements requiring a large sample volume would significantly affect observed processes. A small-volume MPS was designed to minimize the sample volume while still providing high-frequency data. The system was tested for cross-contamination between multiple sources, and two applications of the technology are reported. Cross-contamination from multiple sources was shown to be negligible when using recommended procedures. Shortcircuiting of flow in a bioreactor was directly observed using high-frequency porewater sampling in a well network, and the small-volume MPS showed high seasonal and spatial variability of nitrate removal in stream sediments, enhancing data collected from in situ mesocosms. The results show it is possible to obtain high-frequency data in volume-limited applications. The technology is most promising at the reach or transect scale for observing porewater solute dynamics over daily timescales, with data intervals $<1 \mathrm{~h}$ for up to 12 locations.
\end{abstract}

\section{Advancements in high-frequency water quality monitoring}

Recent UV-VIS field spectrometers provide an opportunity for high-frequency in situ monitoring to increase the temporal resolution of water quality data. Water quality has been measured with these instruments by correlating absorbance with chemical concentration (Crumpton et al., 1992; Suzuki and Kuroda, 1987; Finch et al., 1998; Johnson and Coletti, 2002; Rochelle-Newall and Fisher, 2002; Saraceno et al., 2009). Rieger et al. (2006) and Torres and Bertrand-Krajewski (2008) measured total suspended solids (TSS) in wastewaters using partial least-squares regression (PLSR) to correlate absorbance fingerprints to concentrations. Etheridge et al. (2014) expanded the technique to measure light- and non-absorbing constituents including $\mathrm{PO}_{4}^{3-}$, total phosphorus, nitrate $\left(\mathrm{NO}_{3}^{-}\right)$, total Kjeldahl nitrogen, TSS, dissolved organic carbon, and salinity in a brackish North Carolina marsh. Birgand et al. (2016) have shown that the technique might also be used to measure iron and silica in lakes and reservoirs.

Among the spatial heterogeneity of biological and chemical processes in the environment (Merill and Tonjes, 2014; Kahlert et al., 2002; Dent and Grimm, 1999; Parkin, 1987), patches referred to as "hotspots" are particularly interesting (e.g., riparian buffers, hyporheic zones). These hotspots have been observed to have a disproportionate impact on biogeochemical cycles, and can be particularly active over short periods of time referred to as "hot moments" (McClain et al., 2003; Vidon et al., 2010). While temporal resolution has and will provide invaluable information at a particular moni- 
toring station (e.g., Etheridge et al., 2014), expanding resolution to spatial data could illuminate tightly coupled processes and would greatly magnify the value of these instruments. Documenting the short-term fate of reactive nutrients within identified hotspots might provide new insight into nutrient cycles and their controlling factors.

An automated large volume multiplexed pumping system (MPS) capable of pumping water from up to 12 sources to a UV-VIS spectrophotometer was previously reported (Birgand et al., 2016). The MPS is a "multiplexed" system in that it delivers sample volumes from separate sources to a single probe used to consecutively observe water chemistry at all sources. The $3.18 \mathrm{~mm}$ inside diameter (i.d.) tubing yields an average volume of $100 \mathrm{~mL}$ of water per sample, which is very well adapted when the source can easily accommodate such withdrawal without consequences for the source or the processes studied. Certain applications, however, may require minimizing sample withdrawal to avoid disturbing the observed process while still obtaining high-frequency data. Observing solute dynamics in soils or sediments, particularly those with low drainable porosity, is one such example of a volume-limited application.

In this article, we are reporting the capabilities offered by a small-volume MPS coupled with a field spectrophotometer to obtain high-resolution water quality data in both time and space. This system can accommodate small volumes $(<15 \mathrm{~mL})$ from up to 12 different sources located within a $10 \mathrm{~m}$ distance of the instrument and provide absorbance measurements at better than hourly intervals at each location. This system was designed to minimize inline volumes for volume-limited applications. This article describes the instrument and the challenges involved, evaluates its performance, and reports two applications of this system in such volume-limited conditions.

\section{Small-volume multiplexed pumping system}

The principle followed for this instrument is to use a portable spectrophotometer as a central portable laboratory, coupled with the MPS able to sequentially pump water from several points within a reasonable distance of the probe. The small-volume MPS is designed for high-frequency sampling in volume-limited applications. The solution to minimizing sample volume is small-diameter tubing and a low-volume flow-through measurement cell. The challenges of this design include clogging of tubing and high head losses due to surface tension forces in the tubing. The latter implies higher pump suction and tends to generate sample residuals left after purging along the length of the tubing, increasing the potential for cross-contamination between samples. This drawback demands specific evaluation of the small-volume MPS before use.

\subsection{System design and hardware}

The major components of the system include (1) a UVVIS spectrophotometer fitted with a flow-through cuvette, (2) a bidirectional peristaltic pump, (3) small-diameter polytetrafluoroethylene (PTFE or Teflon) tubing, (4) an Arduino control board (Arduino), (5) a 12-port valve, (6) a three-way valve manifold, and (7) an optional fractional volume collector.

The general automated "sampling sequence" for the system starts with pumping from source $n$ to a flow-through spectrophotometer cuvette via $0.9 \mathrm{~mm}$ i.d. PFTE tubing and a peristaltic pump. After the water has entered the cuvette the spectrophotometer takes a measurement and water is then purged back either to the source, to a fractional volume collector, or to waste using a three-way valve manifold. The multi-port valve then selects source $n+1$, and a similar sampling sequence takes place. Up to 12 sampling sequences corresponding to the 12 ports of the multi-port valve can occur during a "sampling cycle". A fractional volume collector can be used to collect selected sample volumes so that readings by the spectrophotometer can be compared to lab-measured concentrations.

Control of the MPS pumping, purging, valve actuation, and activity logging is performed by an Arduino Mega 53 pin control chip (Arduino, www.arduino.cc). This inexpensive control board utilizes open-source software for easy-to-use programming and hardware interfacing, although other similar board/microprocessors can be used. The high-frequency water quality probe used is a UV-VIS field spectrophotometer Spectro::Lyser ${ }^{\mathrm{TM}}$ by s:: $\mathrm{can}^{\mathrm{TM}}$ fitted with a $4 \mathrm{~mm}$ path length, $1.1 \mathrm{~mL}$ flow-through quartz cuvette (Starna Cells, Inc. model 46-Q-4) placed vertically to facilitate cuvette drainage by gravity during purging. The water quality probe is used as a "master" instrument to dictate to the MPS "slave" system when to begin a sampling sequence. We use an existing capability of the spectrophotometer to send a $12 \mathrm{~V}$ signal at an adjustable time prior to a measurement as a trigger for the MPS, although any other triggering method (e.g., time-based using the Arduino control board) could be used.

A peristaltic pump provides pumping and purging at $20 \mathrm{~mL} \mathrm{~min}^{-1}$ flow rate acceptable for the $0.9 \mathrm{~mm}$ I.D. tubing used. A MOSFET $\mathrm{H}$ bridge controlled by the Arduino reverses DC polarity at the pump to alternate between pumping and purging. The 12-port valve used is a low-pressure Cheminert $^{\mathrm{TM}} 12$-position valve from Valco Instruments. The multi-port valve advances to the next desired port using a pneumatic actuator powered by compressed air (bottle or $12 \mathrm{~V}$ compressor). Although the valve advances through ports sequentially, the user can select the ports to use with the Arduino controller. Three Arduino-controlled three-way solenoid valves (Takasago MTV series) are used for different sampling and purging configurations (Sect. 2.2). The Arduino board is fitted with an SD card reader/writer for activity logging, an RTC clock for timekeeping, an LCD panel 


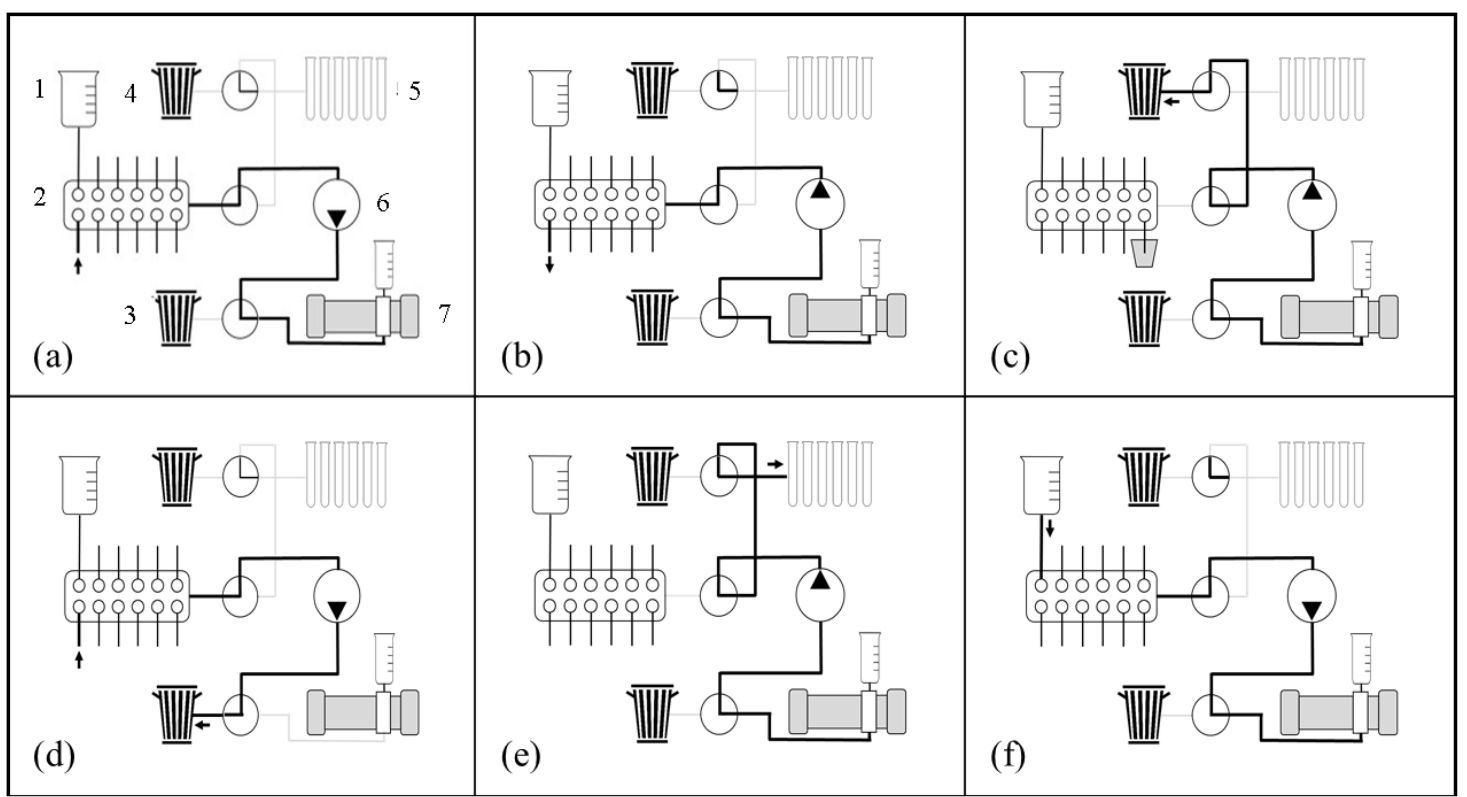

Figure 1. Graphical depiction of small-volume multiplexed pumping system (MPS) configurations which include (1) DI water source, (2) 12port intake valve, $(3,4)$ waste or air purge, (5) fractional volume collector (FVC), (6) bidirectional peristaltic pump, and (7) spectrophotometer with cuvette housing. An Arduino microcontroller actuates a series of three-way valves to move between separate configurations (a-f) described in Sects. 2.2.1-2.2.5.

for system output display, and operable switches for manual control.

The system has been designed for unattended operation for long periods of time (e.g., days or weeks), although it is limited by the spectrometer data storage, fouling of the cuvette, and battery power (and sample storage of the fractional volume collector if used). The time for a sampling sequence is limited by the longest pumping time from furthest source. Ultimately this determines the frequency of spectrometer measurements since the probe has a set time interval between measurements. The sampling frequency for each source depends on the sampling sequence time intervals and on the number of sources (1 to 12).

\subsection{System configurations}

Several configurations have been programmed to increase versatility of the instrument and minimize crosscontamination between samples (Fig. 1) by actuating one or more of the three-way valves using the Arduino control board.

\subsubsection{Pumping from source to probe and purging back to source}

When it is necessary to purge all sample volume back to the source, the system is configured as Fig. 1a during pumping (downward arrow on the peristaltic pump) and as Fig. 1b during purging (upward arrow on the peristaltic pump). To mea- sure absorbance in the $1.1 \mathrm{~mL}$ cuvette used, a minimum sample volume of $\sim 7 \mathrm{~mL}$ is required, which includes cuvette volume ( $\left.V_{\text {cuvette }}\right)$ plus inline tubing volume. The system is purged by air by running the pump in reverse. To minimize cross-contamination without using a deionized (DI) rinse, the cuvette can be rinsed by pumping sample volume $>7 \mathrm{~mL}$ temporarily stored in the post-cuvette storage volume.

\subsubsection{Purge to waste}

In this configuration, it is not desired that the sample be purged to the source, so it is purged to waste (Fig. 1c).

\subsubsection{Pump to waste}

This configuration is used for purging residuals of the sample drawn from the previous source $n-1$ that remain in the tubing and rinsing with sample volume from the current source $n$ (Fig. 1d). After the estimated time for new water from the current source to reach the waste valve has elapsed, the system switches to the configuration in Fig. 1a for sample measurement by probe.

\subsubsection{Fractional volume collection}

This configuration is used for collecting measured sample volumes to compare values given by the probe to later lab analysis (Fig. 1e). The actual sequence consists in purging the fractional volume collector (FVC) tubing with air using Fig. 1e configuration but in the pumping mode (downward 
arrow on the peristaltic pump, not shown) until water has passed the three-way valve closest to the FVC, then use the Fig. 1c configuration to purge any cross-contaminated water to waste before samples are sent to the FVC using the configuration in Fig. 1e. Any water left in tubing after the FVC sample vial is full is purged to waste.

\subsubsection{DI water rinse}

Between each sample, the user may choose to rinse the tubing and cuvette with DI water to create consistent cross-contamination between samples and residual DI water droplets (Fig. 1f). This configuration draws water in from a DI water source and pumps it through the lines and into the cuvette. Consistent cleaning of the quartz cuvette decreases optical fouling over time. The cuvette and post-cuvette storage volume are rinsed and the water is then purged to waste.

\subsection{System testing}

In laboratory continuous flow systems, the risk for crosscontamination between consecutive samples is mechanically minimized by having unidirectional flow and by rinsing the lines with a carrier liquid between samples. Our system has been designed to allow for bidirectional flow, purging the lines instead with air. Because of surface tension forces purging with air can leave micro-droplet residuals in the lines, opening the possibility for cross-contamination between consecutive samples. This is particularly problematic since sample volumes needed for analysis each time are small by design. Although this is admittedly undesirable, this can still be acceptable as long as the potential for contamination is evaluated and solutions to minimize the risks are known. Potential solutions for minimizing cross-contamination include a premeasurement rinse with the current source water or extended purging of the lines with air after each measurement.

Cross-contamination could arise from two processes. First, cuvette contamination could occur when a water sample inside the cuvette during instrument reading is contaminated by droplets from the previous sample, either in the cuvette or in the MPS tubing. Second, cross-contamination of the source, or source contamination, could occur when the "purging back to source" configuration is used (Fig. 1b) and the source itself is contaminated by residuals from other sources. Both contamination possibilities were evaluated in two separate experiments. A third test of performance quantified the relationship between sampling frequency and the distance from the source to the system, since increased pumping time for a sampling sequence leads to lower data frequency.

Methods for evaluating cuvette contamination and source contamination were identical to those used in Birgand et al. (2016). Alternating measurements between sources of high and low $\mathrm{NO}_{3}^{-}$concentration $\left(\left[\mathrm{NO}_{3}\right]_{\text {high }}\right.$ and $\left[\mathrm{NO}_{3}\right]_{\text {low }}$, respectively) were used to determine contamination. The spectrophotometer's estimates of $\mathrm{NO}_{3}^{-}$based on the ab- sorbance fingerprint (method detailed further in the Supplement) were used to quantify contamination. The primary difference in testing the small-volume MPS for contamination between sources was the size of the flow-through cell. In this system a $1.1 \mathrm{~mL}$ flow-through quartz cuvette was used. In addition to testing cross-contamination when rinsing with sample volume from the current source, a DI rinse was tested to see if it resulted in decreased contamination by residuals.

For testing pump timings, external tubes of various lengths were cut and fitted to the inlet port of the system. The length of time required to pump from the source to fill the cuvette and the time required to purge the line were recorded. Pump times for each tube length were measured twice with use of a stopwatch, and average pump time was recorded.

\subsubsection{Cross-contamination results}

The cross-contamination trial results are summarized in Table 1 . The first two columns report $p$ values testing for a significant difference $(\alpha=0.05)$ between spectrophotometric estimates of $\mathrm{NO}_{3}^{-}$concentration in the source (10 repeated measurements) and subsequent 10 measurements after pumping sample volume from the alternate $\mathrm{NO}_{3}^{-}$source between each measurement (i.e., if $p>0.05$, there was no statistical difference between initial and subsequent measurements for $\mathrm{NO}_{3}^{-}$, implying negligible cross-contamination). The results show that without a DI rinse and when measuring high-concentration samples after low-concentration samples, the cuvette must be rinsed with the current sample by at least $10 \times V_{\text {cuvette }}$ to make cuvette contamination by the previous sample negligible. With only rinsing $2 \times V_{\text {cuvette }}$, concentrations were underestimated at about $13.25 \mathrm{mg} \mathrm{NO}_{3}-\mathrm{NL}^{-1}$, lower than the $\left[\mathrm{NO}_{3}\right]_{\text {high }}=14.72 \mathrm{mg} \mathrm{NO}_{3}-\mathrm{NL}^{-1}$ reference. Cross-contamination was divided by 10 by rinsing with $4 \times$ $V_{\text {cuvette }}$, but was still measurable and significant.

For the low-concentration samples measured after high concentrations, rinsing $10 \times V_{\text {cuvette }}$ could not fully eliminate cross-contamination as it still appeared to be significant, yielding readings around $0.14 \mathrm{mg} \mathrm{NO}_{3}-\mathrm{N} \mathrm{L}^{-1}$ instead of the initial $0.06 \mathrm{mg} \mathrm{NO}_{3}-\mathrm{NL}^{-1}$. Adding a DI rinse appeared to eliminate cross-contamination for $\left[\mathrm{NO}_{3}\right]_{\text {low }}$ by rinsing with $10 \times V_{\text {cuvette }}\left(<0.01 \mathrm{mg} \mathrm{L}^{-1}\right.$ difference), but the same treatment significantly diluted $\left[\mathrm{NO}_{3}\right]_{\text {high }}$.

These results suggest that there is not one solution to fully eliminate cross-contamination when consecutive samples differ drastically in solute concentration. These results were obtained for extreme changes of conditions for which consecutive concentrations were roughly 150 -fold different. For applications in which this ratio may be common between consecutive samples, rinsing with $>10 \times V_{\text {cuvette }}$ is recommended and values for lower concentration should be taken with caution. For most applications, however, such ratios between consecutive concentrations are unlikely. For ratios of 50,10 , and 5 (i.e 0.50 to $25.0,0.5$ to 5.0 , and 0.5 to $2.5 \mathrm{mg} \mathrm{NO}_{3}-\mathrm{NL}^{-1}$ ), the differences in mean con- 
Table 1. Results of testing cross-contamination of cuvette. Treatment indicates the volume of sample pumped from the current source for cuvette rinsing relative to cuvette volume ( $\left.V_{\text {cuvette }}\right)$, and whether or not a prior DI rinse was used. C.I. denotes the confidence interval.

\begin{tabular}{|c|c|c|c|c|c|c|c|}
\hline \multirow[t]{2}{*}{$\begin{array}{l}\text { Trial } \\
\text { no. }\end{array}$} & \multirow[t]{2}{*}{ Treatment } & \multicolumn{2}{|c|}{$\begin{array}{c}\text { Initial } \\
\text { concentrations } \\
\left(\mathrm{mg} \mathrm{NO}_{3}-\mathrm{NL}^{-1}\right) \\
\end{array}$} & \multicolumn{2}{|c|}{$\begin{array}{c}p \text { value for } \\
\text { difference in } \\
\text { means of }\end{array}$} & \multicolumn{2}{|c|}{$\begin{array}{c}95 \% \text { C.I. for } \\
\text { difference in means } \\
\left(\mathrm{mg} \mathrm{NO}_{3}-\mathrm{NL}^{-1}\right) \\
\end{array}$} \\
\hline & & {$\left[\mathrm{NO}_{3}\right]_{\mathrm{High}}$} & {$\left[\mathrm{NO}_{3}\right]_{\text {Low }}$} & {$\left[\mathrm{NO}_{3}\right]_{\mathrm{High}}$} & {$\left[\mathrm{NO}_{3}\right]_{\text {Low }}$} & {$\left[\mathrm{NO}_{3}\right]_{\mathrm{High}}$} & low $\mathrm{NO}_{3}^{-}$source \\
\hline 1 & $2 \times V_{\mathrm{cu}}$ & $14.71 \pm 0.02$ & $0.12 \pm$ & $<0.0001$ & $<0.0002$ & $(-1.59,-1.37)$ & $(1.29,2.10)$ \\
\hline 2 & $4 \times V_{\text {cuvette }}$ & $14.71 \pm 0.01$ & $0.09 \pm 0.01$ & $<0.0001$ & $<0.0001$ & $(-0.19,-0.14)$ & $(0.15,0.18)$ \\
\hline 3 & $10 \times V_{\text {cuvette }}$ & $14.75 \pm 0.01$ & $0.06 \pm 0.01$ & $0.236^{*}$ & $<0.0001$ & $(-0.03,0.01)$ & $(0.06,0.09)$ \\
\hline 4 & DI rinse, $2 \times V_{\text {cuvett }}$ & $14.74 \pm 0.01$ & $0.08 \pm 0.01$ & $<0.0001$ & $<0.0001$ & $(-1.74,-1.41)$ & $(0.28,0.35)$ \\
\hline 5 & DI rinse, $4 \times V_{\text {cuvet }}$ & $14.74 \pm 0.01$ & $0.11 \pm 0.02$ & $<0.0001$ & $<0.0001$ & $(-0.11,-0.07)$ & $(0.04,0.08)$ \\
\hline 6 & DI rinse, $10 \times V_{\text {cuvette }}$ & $15.14 \pm 0.01$ & $0.09 \pm 0.02$ & 0.003 & $0.615^{*}$ & $(-0.06,-0.02)$ & $(-0.02,0.04)$ \\
\hline
\end{tabular}

* indicates that the protocol used resulted in no significant difference between the initial $\mathrm{NO}_{3}^{-}$concentration and subsequent measurements $(\alpha=0.05)$

Table 2. Initial $\mathrm{NO}_{3}^{-}$concentrations, calculated effective residual volumes (Vres), and $95 \%$ confidence interval (C.I.) from source contamination trials (a)-(d).

\begin{tabular}{lccc|rrr}
\hline & \multicolumn{3}{c|}{$\left[\mathrm{NO}_{3}\right]_{\text {low }}$} & \multicolumn{4}{c}{$\left[\mathrm{NO}_{3}\right]_{\text {high }}$} \\
\cline { 2 - 7 } Trial & $\begin{array}{c}\text { Initial concentration } \\
\left(\mathrm{mg} \mathrm{NO}_{3}-\mathrm{N} \mathrm{L}^{-1}\right)\end{array}$ & $\begin{array}{c}V_{\text {res }} \\
(\mathrm{mL})\end{array}$ & $\begin{array}{c}95 \% \text { C.I. } \\
(\mathrm{mL})\end{array}$ & $\begin{array}{r}\text { Initial concentration } \\
\left(\mathrm{mg} \mathrm{NO}_{3}-\mathrm{NL}^{-1}\right)\end{array}$ & $\begin{array}{c}V_{\text {res }} \\
(\mathrm{mL})\end{array}$ & $\begin{array}{c}95 \% \text { C.I. } \\
(\mathrm{mL})\end{array}$ \\
\hline (a) & 0.71 & 0.41 & $(0.39,0.43)$ & 15.3 & 0.32 & $(0.29,0.35)$ \\
(b) & 0.71 & 0.35 & $(0.32,0.38)$ & 8.63 & 0.39 & $(0.34,0.43)$ \\
(c) & 0.74 & 0.46 & $(0.38,0.55)$ & 4.80 & 0.28 & $(0.21,0.36)$ \\
(d) & 0.78 & 0.30 & $(0.06,0.52)$ & 2.52 & 0.39 & $(0.15,0.60)$ \\
\hline
\end{tabular}

centrations reported in Table 1 would be divided by a factor of 3,10 , and 30 , respectively. Rinsing with $4 \times V_{\text {cuvette }}$ would reduce the absolute concentration difference from $0.19 \mathrm{mg} \mathrm{NO}_{3}-\mathrm{NL}^{-1}$ in the worst-case scenario to 0.06 , 0.02 , and less than $0.01 \mathrm{mg} \mathrm{NO}_{3}-\mathrm{NL}^{-1}$, respectively, although the concentrations may still be significantly over- or underestimated. These values are within the $5 \%$ measurement uncertainties often found to be acceptable from analytical instruments.

\subsubsection{Source contamination}

Source contamination (or cross-contamination of the source) testing results are shown in Fig. 2. As expected, $\left[\mathrm{NO}_{3}\right]_{\text {high }}$ and $\left[\mathrm{NO}_{3}\right]_{\text {low }}$ became diluted and concentrated, respectively, as residual volumes from the previous samples contaminated the sources. This source contamination increased with increasing difference in initial concentrations (Fig. 2 and Table 3). Over 40 purges back to the source, the concentration and dilution effects were approximately linear, and regression lines were fitted to the data to calculate effective residual volumes $\left(V_{\text {res }}\right)$. The $95 \%$ confidence interval for the slope and intercept of the regression lines was used to calculate the uncertainty on the calculated residual volumes. Standard errors of the regression residuals were twice those of the reference measurements. This indicates additional source(s) of random error, which could include some variability in the residual volumes and/or nonuniform mixing of the sources between consecutive samples. Estimates of $V_{\text {res }}$ were calculated to vary between 0.28 and $0.46 \mathrm{~mL}$ (Table 2). In trials (a) and (c), $V_{\text {res }}$ were statistically different when calculated using $\left[\mathrm{NO}_{3}\right]_{\text {high }}$ and $\left[\mathrm{NO}_{3}\right]_{\text {low }}$, and also differed between trials (a) and (b) for $\left[\mathrm{NO}_{3}\right]_{\text {low }}$. Practically, our results show that when using the purging back to source configuration (Fig. 1b) less than $0.5 \mathrm{~mL}$ of water ( $5 \%$ of sample volume pumped) from the previous sample may contaminate the source measured. This is comparable to previous analysis of the large volume MPS showing $V_{\text {res }}$ of $4 \%$ sample volume pumped (Birgand et al., 2016). This volume may correspond to droplets left in the $0.9 \mathrm{~mm}$ i.d. tubing.

Although this residual volume is significant, its effect depends on the application. When alternating between 3 and $5 \mathrm{mg} \mathrm{NO}_{3}-\mathrm{NL}^{-1}$ of $\mathrm{NO}_{3}^{-}$sources $50 \mathrm{~L}$ in volume, it would take 500 purges to source before a $0.01 \mathrm{mg} \mathrm{NO}_{3}-\mathrm{NL}^{-1}$ change in the concentration would be detectable as a result of residuals purged to the alternate source. In the same situation with a $0.5 \mathrm{~L}$ source, only five purges would induce the same level of change. These results suggest that the purge to source configuration should be used in short-lived experiments and only in applications with a high source volume $(>10 \mathrm{~L})$, which would keep this artifact undetectable. For small-volume applications (e.g., porewater sampling) source 

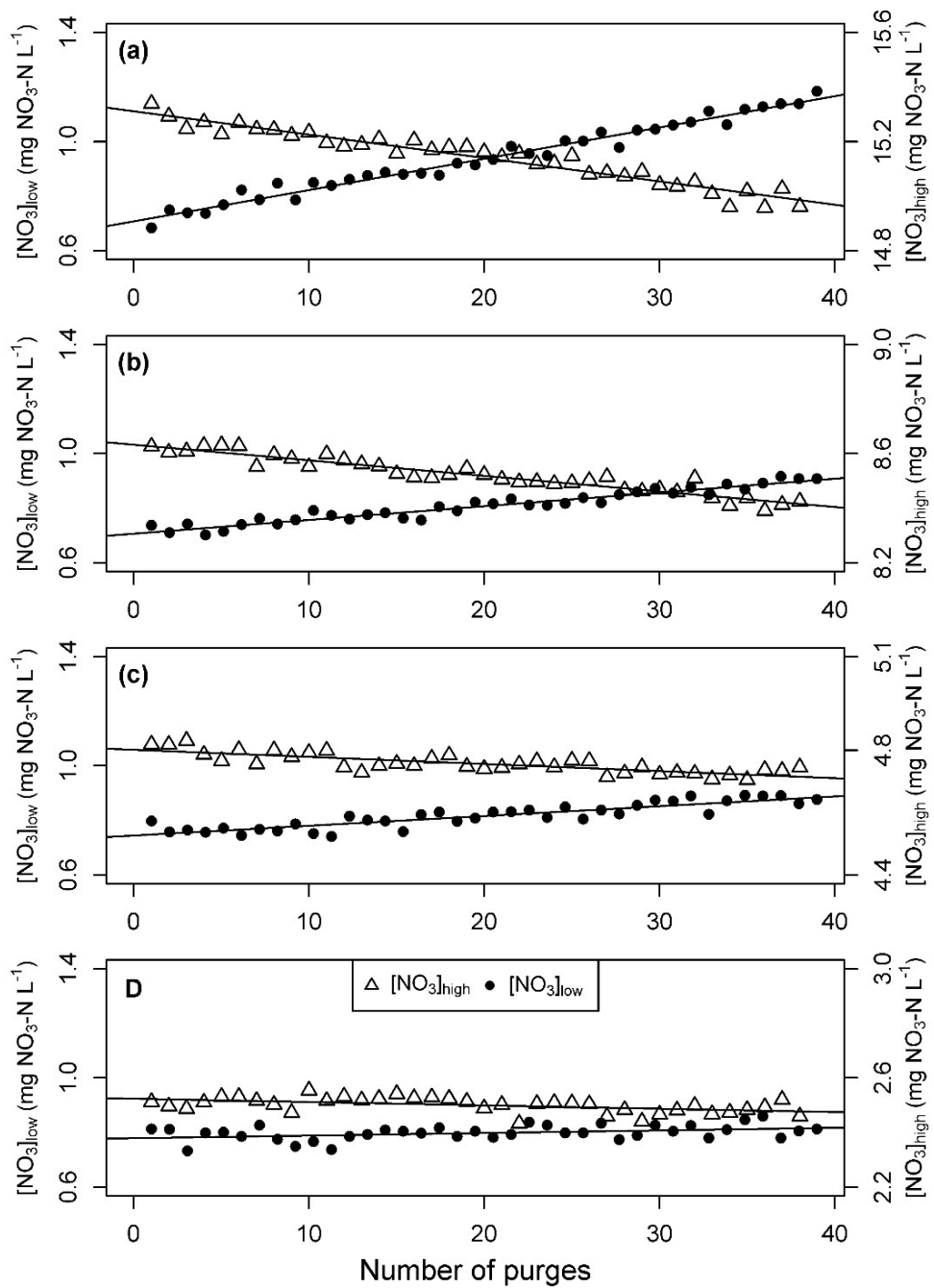

Figure 2. Changes in $\mathrm{NO}_{3}^{-}$concentrations in low $\left(\left[\mathrm{NO}_{3}\right]_{\text {low }}\right)$ and high $\left(\left[\mathrm{NO}_{3}\right]_{\text {high }}\right)$ concentration sources $(0.5 \mathrm{~L})$ resulting from residual volumes purged to the alternate source. Greater concentration or dilution effects were seen with increasing differences in initial $\mathrm{NO}_{3}^{-}$ concentrations of the sources during trials (a)-(d).

contamination may be significant and the "purge to waste" routine is recommended, rather than the purging back to source configuration.

\subsubsection{Pump time requirement results}

Times required for a single sampling sequence (pumping and purging from source) for variable tube lengths were not linear with tubing length (data not shown), and best described using the following equation: time $=0.0001 \times$ length $^{2}+0.0662 \times$ length +79.4 , where time corresponds to the cumulative time in seconds required to pump and purge from the source to the cuvette, and length is the tube length from the source to the MPS in centimeters. From this equation, the time for a sampling sequence between consecutive sources was calculated with $60 \mathrm{~s}$ added to account for cuvette rinsing for the spectrophotometer measurement time. For applications with
Table 3. Zero-order $\mathrm{NO}_{3}^{-}$removal rates, $k$, at eight well locations during five experimental trials. The zero-order kinetics model was fitted to time series of $\mathrm{NO}_{3}^{-}$concentrations after flow to the lab bioreactor was stopped. RMSEP refers to the root mean square error of prediction.

\begin{tabular}{lccc}
\hline $\begin{array}{l}\text { Well } \\
\text { location }\end{array}$ & $\begin{array}{c}\text { Zero order, } k \\
\left(\mathrm{mg} \mathrm{L}^{-1} h^{-1}\right)\end{array}$ & $R^{2}$ & $\begin{array}{c}\text { RMSEP } \\
\left(\mathrm{mg} \mathrm{L}^{-1} h^{-1}\right)\end{array}$ \\
\hline D1 & $0.25-0.43$ & $0.96-0.99$ & $0.002-0.003$ \\
D2 & $0.27-0.43$ & $0.94-0.99$ & $0.002-0.005$ \\
D3 & $0.29-0.38$ & $0.84-0.99$ & $0.002-0.010$ \\
D4 & $0.30-0.38$ & $0.93-0.99$ & $0.001-0.008$ \\
S1 & $0.30-0.44$ & $0.93-0.99$ & $0.002-0.008$ \\
S2 & $0.30-0.54$ & $0.97-0.99$ & $0.002-0.006$ \\
S3 & $0.15-0.34$ & $0.88-0.98$ & $0.003-0.006$ \\
S4 & $0.13-0.36$ & $0.91-0.99$ & $0.001-0.010$ \\
\hline
\end{tabular}


sources up to 1,4 , and $9 \mathrm{~m}$ away from the MPS, the time for one sample sequence would be 147,182 , and $280 \mathrm{~s}$, respectively. The results suggest that roughly $30 \mathrm{~min}$ resolution water quality data can be obtained for up to 10 sources with sources up to $4 \mathrm{~m}$ away. The resolution would fall to $47 \mathrm{~min}$ for the same number of sources up to $9 \mathrm{~m}$ away.

\section{Frequent porewater sampling in a woodchip bioreactor}

Woodchip bioreactors, also called denitrification beds, are a popular agricultural conservation practice for the treatment of $\mathrm{NO}_{3}^{-}$in subsurface drainage. These anaerobic systems provide woodchips as a carbon source and promote denitrification to remove $\mathrm{NO}_{3}^{-}$from the aquatic environment. Soil pits typically $\sim 1 \mathrm{~m}$ deep, $\sim 5 \mathrm{~m}$ wide, and $\sim 25 \mathrm{~m}$ long are filled with woodchips through which drainage water percolates. Over 20 years of research on woodchip bioreactors has shown their potential to reduce $\mathrm{NO}_{3}^{-}$concentrations, but has also shown troubling variability in reported treatment efficacy (e.g., $81 \%$ to $3 \%$; David et al., 2016) or bioreactor volumetric removal rates (e.g., 2 to $22 \mathrm{~g} \mathrm{~N} \mathrm{~m}^{-3} \mathrm{~d}^{-1}$, reviewed by Schipper et al., 2010; 0.42 to $7.76 \mathrm{~g} \mathrm{~N} \mathrm{~m}^{-3} \mathrm{~d}^{-1}$, Christianson et al., 2012). Variation in treatment performance has been attributed to various factors, including hydraulic residence time (HRT), temperature, influent concentration, and age (Addy et al., 2016; Hoover et al., 2016). An important part of the reported uncertainty and variability seems to be associated with measurement methods ill-suited to quantify $\mathrm{NO}_{3}^{-}$fluxes into, within, and leaving bioreactors. Woodchip bioreactors are mostly treated as "black box" systems.

There is evidence that internal hydraulic flow paths and short-circuiting may result in overall treatment inefficiencies, although this has been inferred indirectly in field and lab experiments using tracers (Christianson et al., 2013; Cameron and Schipper, 2011; Hoover et al., 2016). We report results from a preliminary experiment showing that the smallvolume MPS can help improve understanding of bioreactors as black box systems.

\subsection{Materials and methods}

Nitrate dynamics were studied in a $(1.20 \times 1.20 \times 0.45 \mathrm{~m}$ deep) lab bioreactor at North Carolina State University using the small-volume MPS (Figs. S2 and S3 in the Supplement). This bioreactor is a lab-scale model of field bioreactors in which inlet and outlet manifolds installed at opposite corners create diagonal flow from the inlet at the top to the outlet at the bottom (Fig. S2). Eight sampling wells within the bioreactor woodchip media were monitored for $\mathrm{NO}_{3}^{-}$concentrations using the small-volume MPS. Sample wells were placed at shallow $(S)$ or deep $(D)$ zones (20.9 and $41.9 \mathrm{~cm}$ depth, respectively) and at 55.9 and $100.2 \mathrm{~cm}$ from the inlet along two longitudinal transects. Transects were located along the centerline and $21.6 \mathrm{~cm}$ from the left sidewall (Fig. S2). Wells were made of stainless steel tubing $(0.32 \mathrm{~cm}$ O.D.) with vertical slits cut at the tip to draw water into the well. Wells tips were covered with fine plankton netting $(60 \mu \mathrm{m}$ mesh) to prevent clogging of MPS tubing. Well names were assigned based on their location in the bioreactor. Wells S1 and S2 were shallow wells located near the inlet on the centerline and $21.6 \mathrm{~cm}$ from the sidewall, respectively. Wells S3 and S4 were shallow wells located near the outlet on the centerline and $21.6 \mathrm{~cm}$ from the sidewall, respectively. The same convention was used for deep wells D1-D4.

For these experiments a dual sampling-analyzing system was used. The small-volume MPS did not directly sample water from each well. Instead, to obtain synchronized $\mathrm{NO}_{3}^{-}$concentrations in the bioreactor, all wells were sampled simultaneously using an eight-channel ISMATEC peristaltic pump triggered by the MPS Arduino board. The eight-channel pump simultaneously delivered sample volumes from each well to an intermediate manifold of eight $40 \mathrm{~mL}$ syringes. The small-volume MPS was then used to sequentially pump water to the cuvette for analysis by the spectrophotometer. The probe was calibrated for $\mathrm{NO}_{3}^{-}$using PLSR techniques described previously (Etheridge et al., 2014).

\subsection{Small-volume MPS reveals short-circuiting inside a woodchip bioreactor}

In the first MPS application, we conducted a $76 \mathrm{~h}$ constant $\mathrm{NO}_{3}^{-}$injection experiment from 30 April to 4 May 2015 in a saturated bioreactor receiving $60 \mathrm{~L} \mathrm{~h}^{-1}$ tap water flow for a theoretical HRT of $\sim 5.7 \mathrm{~h}$. Nitrate from a concentrated $\mathrm{KNO}_{3}$ stock solution was injected using a precision piston pump (Fluid Metering Inc. Model QBG, $1.2 \mathrm{~g} \mathrm{~L}^{-1}$ ) for a target inflow $\mathrm{NO}_{3}^{-}$concentration of $20 \mathrm{mg} \mathrm{NO}_{3}-\mathrm{NL}^{-1}$. The eight wells were sampled and analyzed every $40 \mathrm{~min}$ with the system described in Sect. 3.1. Ports 9 and 10 of the 12port valve directly sampled the inlet and outlet weirs after consecutively analyzing sample volumes from each of the eight wells. In the first experiment, $\mathrm{KNO}_{3}$ injection began at $08: 10$ on 1 May (14.2 h after MPS monitoring began, Fig. 3). From 14.2 to $22.4 \mathrm{~h} \mathrm{NO}_{3}^{-}$concentrations were stable around $18.3 \mathrm{mg} \mathrm{NO}_{3}-\mathrm{NL}^{-1}$. After this period, inlet concentrations rose until $37 \mathrm{~h}$ and were variable over the $76 \mathrm{~h}$ injection. Inlet $\mathrm{NO}_{3}^{-}$concentration ranged from 18.2 to $20.6 \mathrm{mg} \mathrm{NO}_{3}-\mathrm{NL}^{-1}$ and varied by $12 \%$ of the target inlet concentration. Variability in inlet $\mathrm{NO}_{3}^{-}$concentration was higher than anticipated due to degassing in the $\mathrm{KNO}_{3}$ solution tank, with accumulation of air bubbles partially restricting flow through the piston pump.

Nitrate concentrations at the inlet rose quickly to $18.4 \mathrm{mg} \mathrm{NO}_{3}-\mathrm{NL}^{-1}$ within $47 \mathrm{~min}$ of starting the $\mathrm{KNO}_{3}$ injection (Fig. 3). Inlet $\mathrm{NO}_{3}^{-}$concentration likely passed $18 \mathrm{mg} \mathrm{NO}_{3}-\mathrm{NL}^{-1}$ sooner, but the sampling time resolution of $47 \mathrm{~min}$ was insufficient to capture the exact time of the ar- 


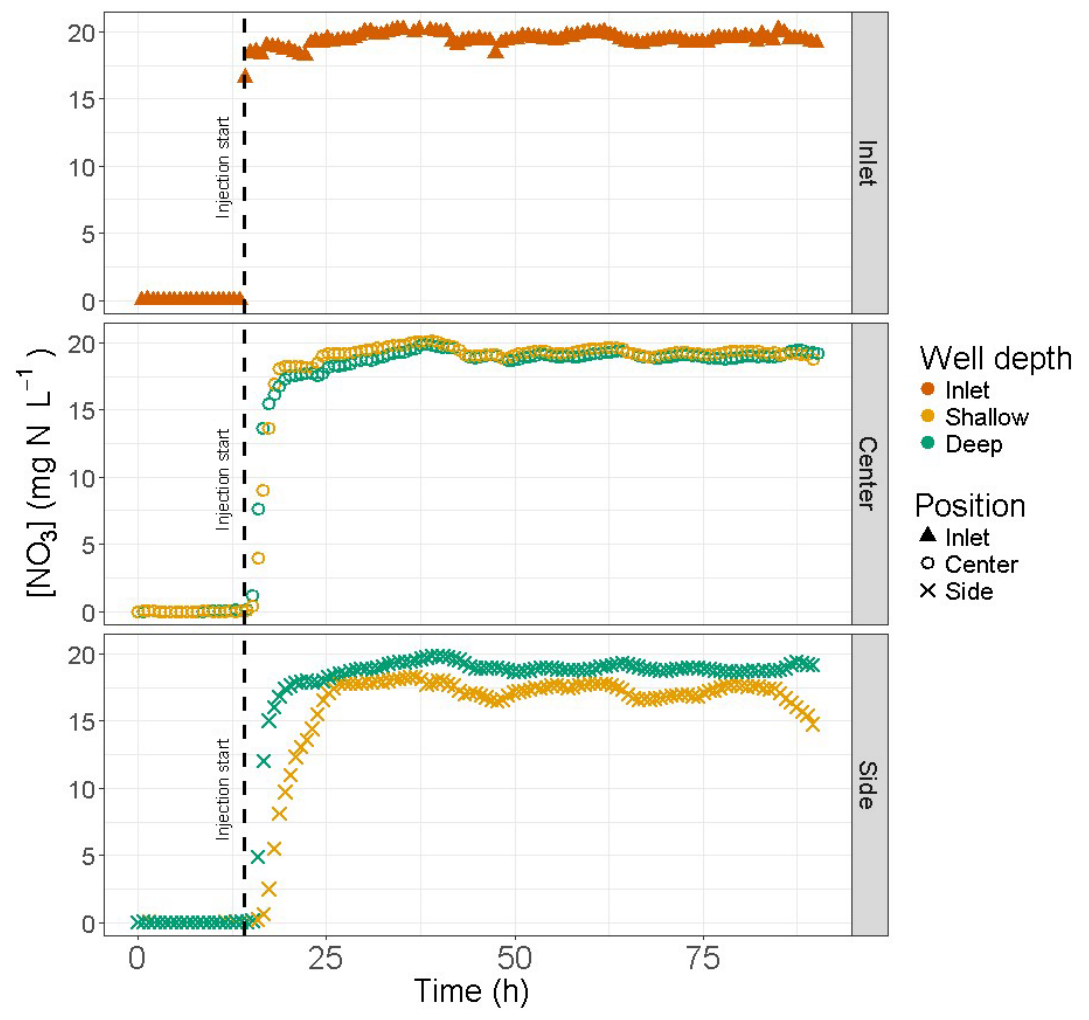

Figure 3. Nitrate concentration at inlet and wells near the inlet before and during the $\mathrm{KNO}_{3}$ injection. Color indicates bioreactor inlet and depth of sampling wells, and shape indicates the position of the well transect (centerline or near the side wall).

rival. Three of the four wells nearest the inlet (S1, D1, and D2) showed nearly identical increases in $\mathrm{NO}_{3}^{-}$, with concentrations at these wells passing $18 \mathrm{mg} \mathrm{NO}_{3}-\mathrm{NL}^{-1}$ within $4.5-8.2 \mathrm{~h}$ of the injection. The shallow inlet well located along the side wall (S2) showed a noticeable lag, with $\mathrm{NO}_{3}^{-}$ staying below $18 \mathrm{mg} \mathrm{NO}_{3}-\mathrm{NL}^{-1}$ until $19.7 \mathrm{~h}$ after the injection began. Nitrate concentrations at this well were significantly lower over the entire injection, relative to other wells near the inlet. All four inlet wells showed increases and decreases in $\mathrm{NO}_{3}^{-}$concentrations that corresponded to changes in concentration at the inlet, although variability at $\mathrm{S} 2$ was much higher than the other three inlet wells. Nitrate concentrations in deep wells near the inlet closely followed one another during each sample interval, with an average difference of only $0.13 \mathrm{mg} \mathrm{NO} \mathrm{N}_{3}-\mathrm{NL}^{-1}$. Shallow wells near the inlet varied greatly, with an average difference of $2.04 \mathrm{mg} \mathrm{NO}_{3}-\mathrm{NL}^{-1}$.

A period of $4 \mathrm{~h}$ after injection, $\mathrm{NO}_{3}^{-}$was detected at the deep middle well near the outlet (D3), but outlet $\mathrm{NO}_{3}^{-}$concentrations did not become stable until about $25 \mathrm{~h}$, or 5 times the theoretical HRT of $5.7 \mathrm{~h}$. The very long lag for stabilization of $\mathrm{NO}_{3}^{-}$concentrations at the outlet weir was likely due to the variability of injected $\mathrm{NO}_{3}^{-}$to move through the bioreactor, as apparent from the $16.9,17.5$, and $21.2 \mathrm{~h}$ taken for $\mathrm{S} 3, \mathrm{~S} 4$, and $\mathrm{D} 3$ to reach $18 \mathrm{mg} \mathrm{NO}_{3}-\mathrm{NL}^{-1}$.
Nitrate concentrations were significantly greater in deep wells relative to shallow wells at side wells near the inlet and at middle wells near the outlet. Shallow wells had higher $\mathrm{NO}_{3}^{-}$concentration at side outlet wells and middle inlet wells. Variance in $\mathrm{NO}_{3}^{-}$concentration was higher in shallow wells than deep wells at all four well pairs, illustrating that water moved quickly diagonally through the bioreactor and short-circuited most of the bioreactor volume. Lag and lower $\mathrm{NO}_{3}^{-}$concentrations observed in the shallow wells (e.g., S2 and S4; Fig. 4) suggest that areas further away from the direct diagonal flow path may have slower hydraulic exchange and higher HRT (e.g., S2) and act as "dead zones".

To the best of our knowledge, short-circuiting and dead zones have never been observed directly but only inferred through dispersion indices (Morrill Dispersion Index) shown in field reactors (Christianson et al., 2013) and in lab reactors (Hoover et al., 2016). Delayed time of arrival for $\mathrm{NO}_{3}^{-}$at wells farther from the shortest flow path indicates hydraulic inefficiencies; however several shallow wells also showed cyclic patterns in $\mathrm{NO}_{3}^{-}$concentrations. Microbial and gas clogging has been documented and can be caused by the creation of biofilm pore walls by microbial cells or fungi (Oberdorfer and Peterson, 1985; Okubo and Matsumoto, 1979; Vandevivere et al., 1995) or by extracellular polymers (Shaw et al., 1985; Vandevivere and Baveye, 1992). Gas clogging 


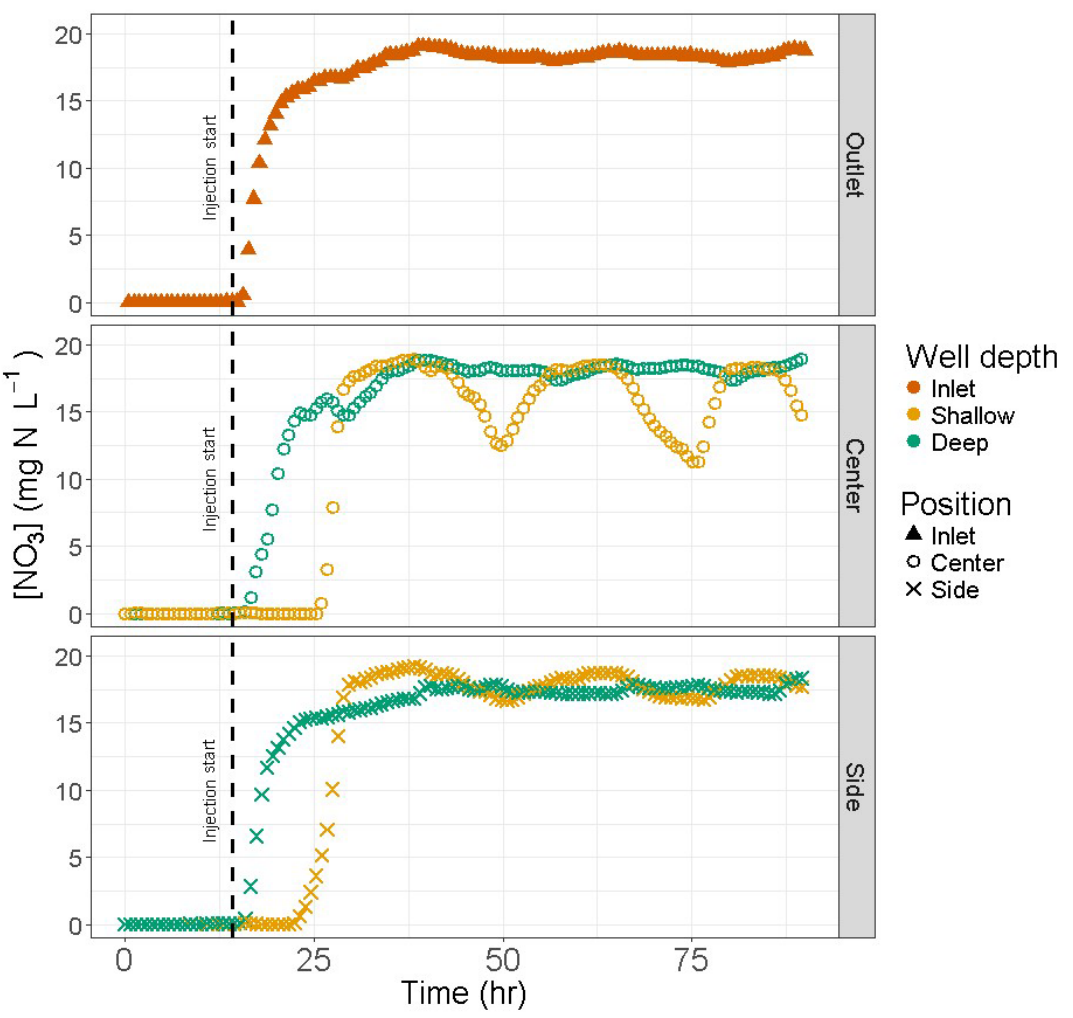

Figure 4. Nitrate concentration at outlet and wells near the outlet before and during the $\mathrm{KNO}_{3}$ injection. Color indicates bioreactor outlet and depth of sampling wells, and shape indicates the position of the well transect (centerline or near the side wall).

due to the accumulation of microbial-produced gas bubbles and influencing hydraulic conductivity in peat (Kellner et al., 2004; Beckwith and Baird, 2001) seems to explain some observed transient low conductivity (Kellner et al., 2004). These changes in hydraulic conductivity could explain the $\mathrm{NO}_{3}^{-}$concentration fluctuations of the $\mathrm{S} 2, \mathrm{~S} 3$, and $\mathrm{S} 4$ wells, which exhibited regular decreases and increases of $\mathrm{NO}_{3}^{-}$concentrations.

\subsection{Internal nitrate removal kinetics}

In a second set of bioreactor experiments, $\mathrm{NO}_{3}^{-}$reduction kinetics were measured at each well. The lab bioreactor was fully drained for a period of $24 \mathrm{~h}$. Following this drain event, the woodchips were re-saturated with the same $\mathrm{KNO}_{3}$ spiked tap water made by the same method described in Sect. 3.2. Inflow $\mathrm{NO}_{3}^{-}$concentration was $14 \mathrm{mg} \mathrm{NO}_{3}-\mathrm{NL}^{-1}$ at $108 \mathrm{Lh}^{-1}$. After pumping 4.5 pore volumes through the reactor, flow was stopped and the outlet weir raised to prevent any outflow. Each well was sampled every $3 \mathrm{~h}$ over $24 \mathrm{~h}$ during five trials from 26 March to 12 April using the MPS and eight-channel pump. Times series of $\mathrm{NO}_{3}^{-}$concentrations at each well were fitted to zero order kinetics models (Eq. 1). Time series were fitted using the nls() function in $\mathrm{R}$ which calculates least-squares estimates for model parame- ters. In fitting the zero-order model, only the concentrations after flow were stopped and above $2 \mathrm{mg} \mathrm{NO}_{3}-\mathrm{NL}^{-1}$ were used. Other than both shallow outlet wells, $\mathrm{NO}_{3}^{-}$concentrations at each well peaked at $12.5-13.5 \mathrm{mg} \mathrm{NO}_{3}-\mathrm{NL}^{-1}$ after flow was stopped. Both shallow outlet wells had much lower peaks of $9.5-10.5 \mathrm{mg} \mathrm{NO}_{3}-\mathrm{N} \mathrm{L}^{-1}$, consistent with observations in the first experiment that wells in this zone were slower to receive new water.

Over the five trials, zero-order $\mathrm{NO}_{3}^{-}$removal rates ranged from 0.13 to $0.54 \mathrm{mg} \mathrm{NO}_{3}-\mathrm{N} \mathrm{L}^{-1} \mathrm{~h}^{-1}$ (Table 3). For this experimental bioreactor with a measured porosity of 0.59 , this equates to a range of $1.84-7.65 \mathrm{~g} \mathrm{~N} \mathrm{~m}^{-3} \mathrm{~d}^{-1}\left(\mathrm{~m}^{3}\right.$ of reactor volume). Having access to eight points provided a range of removal rates and illustrated variability within the bioreactor. Spatial variability in the volumetric $\mathrm{NO}_{3}^{-}$removal rates approached those reported across many field bioreactors (reviewed by Schipper et al., 2010). While there was high variability in $\mathrm{NO}_{3}^{-}$removal rates within trials, there was no significant difference in mean values between wells when considering all five trials. The five lowest removal rates measured (Table 3) were in shallow outlet wells S3 and S4 (observed dead zones), and indicate that there may be a causality between $\mathrm{NO}_{3}^{-}$removal rates and hydraulic inefficiencies or clogging. 


\section{High-frequency measurements in in situ stream mesocosms}

Among the many methods used to measure $\mathrm{NO}_{3}^{-}$removal kinetics in streams, the in situ mesocosm method is attractive as it involves minimal disturbance of the sediment, is effective for investigating spatial variability under field conditions, and can be performed at different times of the year (reviewed by Birgand et al., 2007). In situ mesocosms consist of open-bottom containers inserted into the sediment which isolate water inside the mesocosm from the surrounding stream, making it possible to estimate process kinetics from changes in nutrient concentrations over time. Water recirculation is often applied to mimic ambient stream velocity.

The standard method consists in manual sample withdrawal several times (most often 4-7 times; reviewed by Birgand et al., 2007) over the duration of the experiment (typically $<48 \mathrm{~h}$ ). In laboratory mesocosms the volume of the water withdrawn is a minor issue as one can account for the mass of nutrients removed (e.g., Birgand et al., 2016; Messer et al., 2017). For in situ mesocosms water withdrawal is more significant as this water will, over time, be replaced by water upwelling from the sediment porewater. This discourages taking more samples during the experiment to reduce uncertainty in kinetics estimates. The inherent conflict between kinetics uncertainties and porewater interference in in situ stream mesocosms can be solved with the smallvolume MPS used in the purging back to source configuration (Fig. 1b).

\subsection{Materials and methods}

To characterize $\mathrm{NO}_{3}^{-}$removal kinetics of a stream prior to its restoration (Claridge Nursery, Goldsboro, NC; $35.4^{\circ} \mathrm{N}$, $78.0^{\circ} \mathrm{W}$ ), the small-volume MPS was used with in situ mesocosms in two distinct sections of the reach to be restored. The upper reach of the ditch $(1.6 \mathrm{~km})$ has submerged vegetation and a thick muck sediment $(20-30 \mathrm{~cm}$ depth) with high organic content $(2 \%-26 \%$ organic matter). The lower reach $(0.6 \mathrm{~km})$ has no instream vegetation and sandy sediment with low organic content ( $0.1 \%-9.0 \%$ organic matter). The upper and lower reaches are referred to as Muck and Sand, respectively.

In $1124 \mathrm{~h}$ experimental trials from August 2014 to March 2015, four mesocosms made of open-bottom barrels were gently inserted into the sediment down to approximately $10 \mathrm{~cm}$ within a $1 \mathrm{~m}$ radius of each other (Fig. S4). Each $57 \mathrm{~cm}$ diameter barrel inserted into the sediment is referred to as a Sediment mesocosm and covered $0.26 \mathrm{~m}^{2}$ of the stream bottom. A fifth, closed-bottom barrel (referred to as Control mesocosm) placed in the stream for temperature adjustment and containing only stream water served as a control, representing $\mathrm{NO}_{3}^{-}$removal processes occurring in the water column. Water depth in Sediment mesocosms was measured manually. Recirculating DC pumps $\left(3 \mathrm{~L} \mathrm{~min}^{-1}\right)$ were placed on the sidewall of the barrel (Fig. S5) and their flow was adjusted to mimic ambient stream velocity $\left(0.02-0.10 \mathrm{~m} \mathrm{~s}^{-1}\right)$. Sample lines were placed near the recirculating pumps to obtain a well-mixed sample volume. Mesocosms were removed at the end of each experiment to allow hydrologic connection with the stream between trials. Four $24 \mathrm{~h}$ trials were completed at each Muck site and three trials performed at the downstream Sand site across four seasons.

At the beginning of each trial a $2 \mathrm{~L}$ solution of $\mathrm{KNO}_{3}$ was added to each mesocosm to reach an initial $\mathrm{NO}_{3}^{-}$concentration of $5-6 \mathrm{mg} \mathrm{NO}_{3}-\mathrm{NL}^{-1}$. The overlying water was gently stirred and left to equilibrate. The addition of the $\mathrm{KNO}_{3}$ solution generating extra head inside the mesocosm helped prevent upwelling from groundwater (Solder et al., 2015) which might have otherwise occurred. Each sample volume pumped by the MPS temporarily withdrew $\sim 25 \mathrm{~mL}$ of sample over $<4 \mathrm{~min}$, corresponding to $>0.1 \mathrm{~mm}$ drop in head, which we assumed was not high or long enough to generate significant upwelling.

Mesocosms were sampled every $36 \mathrm{~min}$ for $24 \mathrm{~h}$ using the small-volume MPS. The measurement cuvette $(1.1 \mathrm{~mL}$, $4 \mathrm{~mm}$ path length) was rinsed with $>10 \times V_{\text {res }}$ to prevent cross-contamination. Zero-order, first-order, and efficiency loss (EL) kinetics models accounting for water depth $(D)$ (Eq. 1-3) were fitted to the $\mathrm{NO}_{3}^{-}$concentration time series ( $\sim 40-50$ data points per mesocosm per trial) to (1) compare $\mathrm{NO}_{3}^{-}$removal rates between sites and across seasons and (2) determine which model best predicted the observed data.

$$
\begin{aligned}
C_{t} & =C_{0}-\frac{\rho_{\mathrm{Zo}}}{D} \cdot t \\
C_{t} & =C_{0} \cdot e^{-\left(\frac{\rho_{\mathrm{FO}}}{D} \cdot t\right)} \\
C_{t} & =\left(\frac{\rho_{\mathrm{EL}}^{(\alpha-1)}}{D} \cdot t+C_{0}^{(1-\alpha)}\right)^{\left(\frac{1}{1-\alpha}\right)}
\end{aligned}
$$

Methods of model fitting and evaluation were the same as those presented in Sect. 3.3 (Messer et al., 2017; Birgand et al., 2016). The nls() package in $\mathrm{R}$ Studio was used to fit observed data to a model predicting $\mathrm{NO}_{3}^{-}$concentration at time $t, C_{t}$, from estimates of initial concentration, $C_{0}$, depthcompensated removal constants $\left(\rho_{\mathrm{ZO}}, \rho_{\mathrm{FO}}, \rho_{\mathrm{EL}}\right)$, and the efficiency loss constant $\alpha$. The commonly reported rate constant, $k$, was calculated by dividing $\rho$ coefficients by depth, $D$.

\subsection{Nitrate uptake kinetics}

There was little preference between zero- and first-order models in the time series of decreasing $\mathrm{NO}_{3}^{-}$concentrations (Table 4), with $R^{2}$ values for both models typically $>0.95$. Residuals of both models were nearly identical in most cases and differences in model $\mathrm{R} 2$ were generally $>$ 0.01 . All time series of decreasing $\mathrm{NO}_{3}^{-}$concentrations from Sand trials showed better fit for zero-order kinetics. Higher 
Table 4. Time series of $\mathrm{NO}_{3}^{-}$concentrations in Sediment mesocosms were fitted to zero- and first-order kinetics models. Results indicate that for this short-duration experiment $(<24 \mathrm{~h})$ and at the observed range of $\mathrm{NO}_{3}^{-}$concentrations $\left(2-6 \mathrm{mg} \mathrm{NO}_{3}-\mathrm{NL}^{-1}\right)$, removal was described equally well by either model, although first-order kinetics better fitted $\mathrm{NO}_{3}^{-}$time series during trials with large changes in $\mathrm{NO}_{3}^{-}$ concentration. RMSEP refers to the root mean square error of prediction.

\begin{tabular}{lrrcrrr}
\hline $\begin{array}{l}\text { Trial date } \\
\text { (sediment) }\end{array}$ & $\begin{array}{r}\text { Zero order, } k \\
\mathrm{mg} \mathrm{NO}_{3}-\mathrm{N} \mathrm{m}^{-2} \mathrm{~d}^{-1}\end{array}$ & & $\begin{array}{c}R^{2} \\
\mathrm{~m} \mathrm{NO}_{3}-\mathrm{N} \mathrm{m}^{-2} \mathrm{~d}^{-1}\end{array}$ & $\begin{array}{c}\text { First order, } k \\
\mathrm{~m} \mathrm{~d}^{-1}\end{array}$ & $\begin{array}{c}R^{2} \\
\text { RMSEP } \\
\mathrm{m} \mathrm{d}^{-1}\end{array}$ \\
\hline 28 Aug (Muck) & $500-580$ & 0.99 & $30-60$ & $0.15-0.17$ & 0.99 & $0.02-0.05$ \\
1O Oct (Muck) & $200-250$ & $0.95-0.98$ & $30-60$ & $0.06-0.07$ & $0.95-0.98$ & $0.03-0.05$ \\
6 Nov (Muck) & $140-260$ & $0.93-0.98$ & $40-70$ & $0.04-0.07$ & $0.93-0.98$ & $0.03-0.06$ \\
13 Nov (Muck) & $160-200$ & $0.89-0.98$ & $20-60$ & $0.05-0.06$ & $0.89-0.98$ & $0.02-0.06$ \\
29 Jan (Muck) & $-40-180$ & $0.00-0.93$ & $10-40$ & $0.00-0.05$ & $0.00-0.93$ & $0.00-0.04$ \\
3 Feb (Muck) & $40-120$ & $0.76-0.99$ & $20-30$ & $0.01-0.04$ & $0.76-0.99$ & $0.02-0.03$ \\
11 Mar (Muck) & $180-320$ & $0.93-0.99$ & $20-40$ & $0.04-0.09$ & $0.92-0.99$ & $0.02-0.04$ \\
18 Mar (Muck) & $90-300$ & $0.97-0.99$ & $20-60$ & $0.03-0.13$ & $0.97-0.99$ & $0.02-0.05$ \\
18 Sep (Sand) & $10-110$ & $0.10-0.86$ & $20-50$ & $0.00-0.03$ & $0.10-0.85$ & $0.02-0.05$ \\
17 Dec (Sand) & $140-240$ & $0.97-0.98$ & $20-30$ & $0.03-0.06$ & $0.96-0.98$ & $0.02-0.03$ \\
16 Mar (Sand) & $20-50$ & $0.63-0.84$ & $20-30$ & $0.01-0.02$ & $0.63-0.86$ & $0.02-0.03$ \\
\hline
\end{tabular}

$R^{2}$ and improved residuals for a first-order model, relative to a zero-order model, were seen in trials with greater decreases in $\mathrm{NO}_{3}^{-}$concentrations over the experiment. This was the case in 18 March and 28 August trials during which net $\mathrm{NO}_{3}^{-}$reduction in several mesocosms approached 2$3 \mathrm{mg} \mathrm{NO}{ }_{3}-\mathrm{NL}^{-1}$ over $24 \mathrm{~h}$. The poorest model fitting occurred when fitting models to time series with little to no reduction in $\mathrm{NO}_{3}^{-}$concentrations, when total variability of $\mathrm{NO}_{3}^{-}$was close to the precision of the spectrophotometer or transient, short-term changes in $\mathrm{NO}_{3}^{-}$were large relative to net reduction. The EL model was not useful in these shortterm experiments.

These results are somewhat contradictory to results obtained in lab wetland mesocosms of similar size, whereby data were not fitted well by a zero-order model and whereby the EL model performed best (Birgand et al., 2016). It is possible that the experiments were not of long enough duration for $\mathrm{NO}_{3}^{-}$concentrations to decrease enough for differences to appear among models, or for first-order and EL kinetics to be apparent. In these in situ experiments, the results suggest that $\mathrm{NO}_{3}^{-}$removal kinetics at the diurnal scale in nutrient-rich streams were adequately predicted by zero-order models. In Muck trials, $\rho$ values ranged from 10 to $580 \mathrm{mg} \mathrm{NO}_{3}-\mathrm{N} \mathrm{m}^{-2} \mathrm{~d}^{-1}$ (Table 4). Removal rates in Sand mesocosms were much lower, ranging from 10 to $240 \mathrm{mg} \mathrm{NO}_{3}-\mathrm{N} \mathrm{m}^{-2} \mathrm{~d}^{-1}$. The results show that for $\mathrm{NO}_{3}^{-}$removal rates less than $300 \mathrm{mg} \mathrm{N} \mathrm{m}^{-2} \mathrm{~L}^{-1}$, the zero-order rate model was sufficient to fit the data, but the first-order model appeared better for higher $\mathrm{NO}_{3}^{-}$removal rates generally found in agricultural streams (350 and $1250 \mathrm{mg} \mathrm{N} \mathrm{m}^{-2} \mathrm{~d}^{-1}$; Birgand et al., 2007).

\subsection{Seasonal and spatial variability}

In Muck trials $\mathrm{NO}_{3}^{-}$removal rates followed a predictable seasonal pattern, with removal rates highest in the month of August, decreasing in October and November trials, lowest during the winter months, and increasing again during March. This is consistent with observations that the rates of microbial processes increase with temperature. Nitrate removal rates during the 18 August trial $\left(25^{\circ} \mathrm{C}\right)$ were $4-14$ times greater than those during 3 February $\left(8^{\circ} \mathrm{C}\right)$ at the same site. The opposite trend was seen among Sand trials. The 17 December trial with the coldest temperatures among Sand trials $\left(10^{\circ} \mathrm{C}\right)$ showed the highest $\mathrm{NO}_{3}^{-}$removal rates. A seasonal influx of available carbon was likely the cause of this trend. Accumulated leaf packs at the Sand site, included in the 17 December mesocosms, provided available carbon and substrate for denitrification to occur. Nitrate removal rates during this trial were even higher than rates in Muck trials with similar temperature (29 January and 3 Februry).

The in situ mesocosm method revealed high variability in $\mathrm{NO}_{3}^{-}$removal rates within trials, even when mesocosms were within a $1 \mathrm{~m}$ radius. High variability in Muck trials in the month of March was caused by the presence of emergent vegetation along the stream bank (Fig. S6). In 11 and 18 March trials, mesocosms placed in this near-bank vegetated zone showed removal rates $48 \%-81 \%$ and $74 \%-240 \%$ higher than those in mesocosms placed in the unvegetated stream center, respectively. In the 29 January trial, a single mesocosm showed removal rates 300\%-2500\% higher than the other Sediment mesocosms. Muck trials had a higher degree of within-trial variability relative to Sand, indicating that sediment $\mathrm{NO}_{3}^{-}$removal potential at the Sand site was more homogenous. 


\section{Conclusions}

The first report of the MPS illustrated the ability of this technology to increase temporal and spatial resolution of water quality data (Birgand et al., 2016). The smallvolume MPS increases the number of potential applications for this method by significantly decreasing sample volume. The small-volume MPS minimized the volume of the flow-through measurement cell ( $1.1 \mathrm{~mL}$ quartz cuvette), contrasting with the $40 \mathrm{~mL}$ flow-through cell used previously. In order to prevent cross-contamination of samples caused by pumping from different sources, an adequate premeasurement rinse with the current sample volume must be used. For the larger volume MPS this would require pumping roughly 36 times more volume past the flow-through cell for adequate rinsing. In the stream mesocosms, removing $25 \mathrm{~mL}$ of sample for $<4$ min to measure absorbance resulted in a temporary head drop $<0.1 \mathrm{~mm}$ and minimized sample withdrawal to allow $40-50 \mathrm{NO}_{3}^{-}$measurements to be made over $24 \mathrm{~h}$ without significantly affecting mesocosm hydraulics.

The small-volume MPS allows continuous multi-point sampling to be extended to applications for which the sample volume is limited or must be minimized. The most obvious application is for porewater sampling, for which sample withdrawal rate should not exceed the rate at which water moves through the medium. Total volume extracted must also be small to avoid significantly affecting the observed environment. Drainable porosity in soils is much less than the total volume of soil, leading to a zone of influence in which the size depends on the total sample volume extracted and the drainable porosity. For example, if sampling every 1 or $6 \mathrm{~h}$ over $24 \mathrm{~h}$ from a soil with a 0.1 drainable porosity, this zone of influence (assuming $15 \mathrm{~mL}$ required sample volume for the small-volume MPS) would be 3600 and $600 \mathrm{~cm}^{3}$, respectively. Assuming this zone is spherical, it would have a diameter of 19 and $10 \mathrm{~cm}$, which is not insignificant. The sampling interval should be short enough to adequately capture temporal variation while avoiding excessive water withdrawal to avoid interdependence between sampling points that are hydraulically connected. When removal kinetics were measured in the lab bioreactor during stopped flow, a sample interval of $3 \mathrm{~h}$ was used over $24 \mathrm{~h}$. With an observed drainable porosity of 0.58 , the zone of influence at each of the eight points was $7.3 \mathrm{~cm}$ and accounted for $0.4 \%$ of water in the bioreactor. Sampling wells were no closer than $21 \mathrm{~cm}$, so an assumption of independence between sampling points was reasonable.

For the first time, the small-volume MPS was able to observe short-circuiting in a woodchip bioreactor, which had been surmised in the literature although never fully shown. We were also able to measure $\mathrm{NO}_{3}^{-}$removal rates at multiple locations within the bioreactor. The application of the MPS in stream mesocosms has allowed the possibility to measure $\mathrm{NO}_{3}^{-}$removal kinetics in situ in replicated experiments by eliminating potential contamination by groundwa- ter. The small-volume MPS has high potential for providing quality data sets for improving new and existing solute transport models for saturated or partially saturated soils and presents the possibility of being used in replicated experiments.

Due to the small diameter of the fittings and tubing in this system, several pumping concerns are magnified compared to the large volume MPS. Water micro-droplets or residuals in the tubing lines are more susceptible to freezing and caution should be used when deploying this system under freezing conditions. Valves and tubing are also more susceptible to clogging. In both applications a plankton net fabric $(60 \mu \mathrm{m}$ mesh) was used and no clogging occurred, even in the case of the woodchip bioreactor application with high dissolved organic matter. The small sample volume potentially limits the number of sondes and sensors to which the MPS can be coupled. The design of the s::can spectrophotometer allows for such a small-volume flow-through measurement cell to be used, while other available water quality sensors typically require much larger sample volumes for which this system might not be well suited. The volumelimited applications presented include sampling an overlying water column and porewater in coarse woodchips. Porewater sampling in fine soils or sediments may be more restrictive and will result in a larger sphere of influence around the sampling point. While the minimum volume required for measurement using the MPS is small $(\sim 7 \mathrm{~mL})$ and comparable to other small-volume sediment samplers (e.g., Rhizon in situ samplers; Seeberg-Elverfeldt et al., 2005), bidirectional pumping from multiple sources by the MPS requires a volume closer to $10-15 \mathrm{~mL}$ to reduce cross-contamination for accurate solute measurement. Sampling of fine soils with low hydraulic conductivity using the MPS can be aided by the use of small-diameter sampling wells, similar to those described in Sect. 3.1.

Data availability. All data presented in this paper in Sects. 2.3.1, 2.3.2, 3.1, 3.2, 4.2, and 4.3 are provided in .csv files in an online Zenodo repository at https://doi.org/10.5281/zenodo.1453353 (Maxwell, 2018). The online repository also includes the $\mathrm{R}$ code (R Studio Ver.1.1.442 or greater) used to generate plots and calculate coefficients for $\mathrm{NO}_{3}^{-}$removal kinetic equations.

\section{The Supplement related to this article is available online at: https://doi.org/10.5194/hess-22-5615-2018- supplement}

Author contributions. Direction of research, funding, and initial development of the small-volume MPS was provided by FB. Early design and prototyping of the small-volume MPS was provided by $\mathrm{BS}$ and $\mathrm{KAD}$, and development of protocols for testing crosscontamination was contributed to by KAD. 
Competing interests. The authors declare that they have no conflict of interest.

Acknowledgements. The authors would like to acknowledge the NCSU BAE Environmental Analysis Lab for water chemistry analysis. Stream mesocosm research was funded by the NCDOT under grant agreement 2013-37, and bioreactor porewater sampling research was funded in part by NIFA USDA grant 2016-6701925279 and USDA multistate project S1063.

Edited by: Matthew Hipsey

Reviewed by: two anonymous referees

\section{References}

Addy, K., Gold, A., Christianson, L., David, M., Schipper, L., and Ratigan, N.: Denitrifying bioreactors for nitrate removal: A metaanalysis, J. Environ. Qual., 45, 873-871, 2016.

Beckwith, C. W. and Baird, A. J.: Effect of biogenic gas bubbles on water flow through poorly decomposed blanket peat, Water Resour. Res., 37, 551-558, 2001.

Birgand, F., Skaggs, R. W., Chescheir, G. M., and Gilliam, J. W.: Nitrogen removal in streams of agricultural catchments - a literature review, Crit. Rev. Env. Sci. Tec., 37, 381-487, 2007.

Birgand, F., Aveni-Deforge, K., Smith, B., Maxwell, B., Horstman, M., Gerling, A. B., and Carey, C. C.: First report of a novel multiplexer pumping system coupled to a water quality probe to collect high temporal frequency in situ water chemistry measurements at multiple sites, Limnol. Oceanogr.-Meth., 14, 767-783, 2016

Cameron, S. G. and Schipper, L. A.: Evaluation of passive solar heating and alternative flow regimes on nitrate removal in denitrification beds, Ecol. Eng., 37, 1195-1204, 2011.

Christianson, L., Helmers, M., Bhandari, A., and Moorman, T.: Internal hydraulics of an agricultural drainage denitrification bioreactor, Ecol. Eng., 52, 298-307, 2013.

Christianson, L. E., Bhandari, A., Helmers, M. J., Kult, K. J., Sutphin, T., and Wolf, R.: Performance evaluation of four fieldscale agricultural drainage denitrification bioreactors in iowa, T. ASABE, 55, 2163-2174, 2012.

Crumpton, W. G., Isenhart, T. M., and Mitchell, P. D.: Nitrate and organic $\mathrm{N}$ analyses with second-derivative spectroscopy, Limnol. Oceanogr., 37, 907-913, 1992.

David, M. B., Gentry, L. E., Cooke, R. A., and Herbstritt, S. M.: Temperature and substrate control woodchip bioreactor performance in reducing tile nitrate loads in east-central illinois, J. Environ. Qual., 45, 822-829, 2016.

Dent, C. L. and Grimm, N. B.: Spatial heterogeneity of stream water nutrient concentrations over successional time, Ecology, 80, 2283-2298, 1999.

Etheridge, J. R., Birgand, F., Osborne, J. A., Osburn, C. L., Burchell, M. R., and Irving, J.: Using in situ ultraviolet-visual spectroscopy to measure nitrogen, carbon, phosphorus, and suspended solids concentrations at a high frequency in a brackish tidal marsh, Limnol. Oceanogr.-Meth., 12, 10-22, 2014.

Finch, M. S., Hydes, D. J., Clayson, C. H., Weigl, B., Dakin, J., and Gwilliam, P.: A low power ultra violet spectrophotometer for measurement of nitrate in seawater: Introduction, calibration and initial sea trials, Anal. Chim. Acta, 377, 167-177, 1998.

Johnson, K. S. and Coletti, L. J.: In situ ultraviolet spectrophotometry for high resolution and long-term monitoring of nitrate, bromide and bisulfide in the ocean, Deep-Sea Res. Pt I, 49, 12911305, 2002.

Kahlert, M., Hasselrot, A. T., Hillebrand, H., and Pettersson, K.: Spatial and temporal variation in the biomass and nutrient status of epilithic algae in lake erken, sweden, Freshwater Biol., 47, 1191-1215, 2002.

Kellner, E., Price, J. S., and Waddington, J.: Pressure variations in peat as a result of gas bubble dynamics, Hydrol. Process., 18, 2599-2605, 2004.

Maxwell, B.: Replication data for : A small volume multiplexed pumping system for automated, high frequency water chemistry measurements in volume-limited applications, Zenodo, https://doi.org/10.5281/zenodo.1453353, 2018.

McClain, M. E., Boyer, E. W., Dent, C. L., Gergel, S. E., Grimm, N. B., Groffman, P. M., Hart, S. C., Harvey, J. W., Johnston, C. A., and Mayorga, E.: Biogeochemical hot spots and hot moments at the interface of terrestrial and aquatic ecosystems, Ecosystems, 6, 301-312, 2003.

Merill, L. and Tonjes, D. J.: A review of the hyporheic zone, stream restoration, and means to enhance denitrification, Crit. Rev. Env. Sci. Tec., 44, 2337-2379, 2014.

Messer, T. L., Burchell II, M. R., Birgand, F., Broome, S. W., and Chescheir, G.: Nitrate removal potential of restored wetlands loaded with agricultural drainage water: A mesocosm scale experimental approach, Ecol. Eng., 106, 541-554, 2017.

Oberdorfer, J. A. and Peterson, F. L.: Waste-water injection: Geochemical and biogeochemical clogging processes, Groundwater, 23, 753-761, 1985.

Okubo, T. and Matsumoto, J.: Effect of infiltration rate on biological clogging and water quality changes during artificial recharge, Water Resour. Res., 15, 1536-1542, 1979.

Parkin, T. B.: Soil microsites as a source of denitrification variability, Soil Sci. Soc. Am. J., 51, 1194-1199, 1987.

Rieger, L., Langergraber, G., and Siegrist, H.: Uncertainties of spectral in situ measurements in wastewater using different calibration approaches, Water Sci. Technol., 53, 187-197, 2006.

Rochelle-Newall, E. and Fisher, T.: Chromophoric dissolved organic matter and dissolved organic carbon in chesapeake bay, Mar. Chem., 77, 23-41, 2002.

Saraceno, J. F., Pellerin, B. A., Downing, B. D., Boss, E., Bachand, P. A., and Bergamaschi, B. A.: High-frequency in situ optical measurements during a storm event: Assessing relationships between dissolved organic matter, sediment concentrations, and hydrologic processes, J. Geophys. Res., 114, G00F09, https://doi.org/10.1029/2009JG000989, 2009.

Seeberg-Elverfeldt, J., Schlüter, M., Feseker, T., and Kölling, M.: Rhizon sampling of porewaters near the sediment-water interface of aquatic systems, Limnol. Oceanogr.-Meth., 3, 361-371, 2005.

Schipper, L. A., Robertson, W. D., Gold, A. J., Jaynes, D. B., and Cameron, S. C.: Denitrifying bioreactors - an approach for reducing nitrate loads to receiving waters, Ecol. Eng., 36, 15321543, 2010.

Shaw, J. C., Bramhill, B., Wardlaw, N. C., and Costerton, J. W.: Bacterial fouling in a model core system, Appl. Environ. Microb., 49, 693-701, 1985. 
Solder, J. E., Gilmore, T. E., Genereux, D. P., and Solomon, D. K.: A tube seepage meter for in situ measurement of seepage rate and groundwater sampling, Groundwater, 54, 588-595, 2016.

Suzuki, N. and Kuroda, R.: Direct simultaneous determination of nitrate and nitrite by ultraviolet second-derivative spectrophotometry, Analyst, 112, 1077-1079, 1987.

Torres, A. and Bertrand-Krajewski, J.-L.: Partial least squares local calibration of a UV-visible spectrometer used for in situ measurements of cod and tss concentrations in urban drainage systems, Water Sci. Technol., 57, 581-588, 2008.
Vandevivere, P. and Baveye, P.: Effect of bacterial extracellular polymers on the saturated hydraulic conductivity of sand columns, Appl. Environ. Microb., 58, 1690-1698, 1992.

Vandevivere, P., Baveye, P., Lozada, D. S., and DeLeo, P.: Microbial clogging of saturated soils and aquifer materials: Evaluation of mathematical models, Water Resour. Res., 31, 2173-2180, 1995.

Vidon, P., Allan, C., Burns, D., Duval, T. P., Gurwick, N., Inamdar, S., Lowrance, R., Okay, J., Scott, D., and Sebestyen, S.: Hot spots and hot moments in riparian zones: Potential for improved water quality management, J. Am. Water Resour. As., 46, 278-298, 2010. 